JURNAL PENELITIAN PETERNAKAN TERPADU

Volume 1 (1), Oktober 2019 : 44-51

http://jurnal.polbangtanyoma.ac.id/index.php/jppt

\title{
Pengaruh Perbedaan Aras Starter Aspergilus Niger Pada Proses Amofer Sekam Padi Terhadap Kandungn Lignin, Selulosa Dan Hemiselulosa
}

\section{The Effect of Aspergillus niger Starter Level Differences in Rice Hull Ammoniated-Fermentation on Lignin, Cellulose and Hemicellulose}

\author{
Ditto Satria Pambudi, Baginda Iskandar MudaTampoebolon, dan Surahmanto \\ Fakultas Peternakan dan Pertanian Universitas Diponegoro, Semarang \\ dittosatria8@gmail.com
}

Disetuju : 25 September 2019

\begin{abstract}
ABSTRAK
Penelitian amoniasi fermentasi sekam padi bertujuan untuk mengkaji pengaruh perlakuan perbedaan aras starter kapang $A$. niger pada proses fermentasi sekam padi yang telah diamoniasi terhadap kandungan lignin, selulosa dan hemiselulosa. Penelitian ini menggunakan Rancangan Acak Lengkap (RAL) dengan 3 perlakuan menggunakan 5 ulangan. Perlakuan yang diberikan yaitu perbedaan pemberian aras starter yaitu : 0\% ( $\left.T_{0}\right), 2,5 \%\left(T_{1}\right)$ dan $5 \%\left(T_{2}\right)$. Sekam padi diamoniasi terlebih dahulu dengan kadar amonia 5\% selama 21 hari, kemudian dilanjutkan dengan proses fermentasi dengan aras starter A. niger selama 10 hari. Parameter yang diamati adalah kandungan lignin, selulosa dan hemiselulosa. Data yang diperoleh diuji dengan analisis ragam pada taraf $5 \%$. Apabila terdapat pengaruh nyata $(P<0,05)$, diuji lanjut menggunakan uji wilayah ganda Duncan untuk mengetahui perbedaan nilai tengah antar perlakuan. Hasil penelitian menunjukkan bahwa perbedaan aras starter $A$. niger berpengaruh nyata $(P<0,05)$ menurunkan kandungan hemiselulosa dan selulosa sekam padi amoniasi yang telah di fermentasi. Kesimpulan dari penelitian ini adalah penambahan aras starter $A$. niger dalam proses fermentasi sekam padi amoniasi dapat menurunkan kadar selulosa dan hemiselulosa.
\end{abstract}

Kata kunci : fermentasi, amoniasi, lignin, selulosa, hemi

\section{ABSTRACT}

Research on ammoniation of rice husk fermentation aimed to examine the effect of different starter levels of Aspergillus niger in fermentation process on rice husk that had been fermented on lignin, selulosa and hemiselulosa. This study used a completely randomized design with 3 treatments using 5 replications. The difference in given starter level were $0 \%\left(T_{0}\right), 2,5 \%\left(T_{1}\right)$ and $5 \%\left(T_{2}\right)$. Rice hull first ammoniated with $5 \%$ ammonia 
level for 21 days, then the fermentation process continued with various starter levels for 10 days. Parameters observed were lignin, cellulose and hemicellulose. Data obtained were tested by analysis of variance at the level $5 \%$. If there is a significant effect $(P<0.05)$, it is tested further using the Duncan's multiple range test to find out the difference between treatments. The result showed that the difference of A. niger as starter significantly $(P<0.05)$ decreased cellulose and hemicellulose in rice husk that had been fermented. In conclusion, additions of different starter levels of Aspergillus niger in fermentation process on rice husk that had been fermented could decrease cellulose and hemicellulose.

Key words : fermentation, ammoniation, lignin, cellulose, hemicellulose.

\section{PENDAHULUAN}

Sekam padi merupakan kulit padi yang terpisah dari butir beras. Sekam padi diperoleh dari proses penggilingan padi, kulit padi akan terpisah dari butir beras dan menjadi bahan sisa atau hasil samping penggilingan padi. Hasil samping (sekam padi) yang dihasilkan cukup berlimpah karena beras merupakan makanan pokok masyarakat Indonesia (Partama et al., 2018). Produksi padi lebih kurang sebanyak 9,51 juta ton GKG (Gabah Kering Giling) setara dengan 5,44 juta ton beras dan sekam yang dihasilkan sekitar $19 \%$ atau sebanyak 1,81 juta ton (BPS Jawa Tengah, 2018). Sekam padi dapat digolongkan sebagai bahan pakan alternatif. Dedak padi yang banyak dijual saat ini banyak yang dicampur dengan sekam padi giling yang tidak diolah sehingga berkualitas rendah dan merugikan peternak. Sekam padi tanpa perlakuan tergolong bahan pakan yang berkualitas sangat rendah serta pemanfaatannya masih belum optimal. Sekam padi memiliki kandungan $24,3 \%$ hemiselulosa, 34,4\% selulosa, dan 19,2\% lignin (Soltani et al., 2015).
Teknologi pengolahan pakan dengan amoniasi dan fermentasi (amofer) merupakan salah satu upaya dalam peningkatan kualitas bahan pakan yang telah banyak dilakukan. Proses amoniasi dan fermentasi mempunyai kelebihan antara lain: tidak mempunyai efek samping yang negatif, mudah dilakukan, relatif tidak membutuhkan peralatan khusus dan biaya relatif murah. Salah satu fungsi amoniasi adalah dapat merenggangkan dan bahkan memutus sebagian ikatan antara lignin, selulosa dan hemiselulosa, sehingga dalam proses fermentasi starter (mikroba) akan jauh lebih mudah mendegradasi bahan selulosa dan hemiselulosa. Proses fermentasi dapat menurunkan kadar serat sekaligus meningkatkan kecernaan dan kandungan protein kasar bahan (Sukaryana et al., 2011).

Penelitian ini bertujuan untuk mengkaji pengaruh perlakuan perbedaan aras starter kapang $A$. niger pada proses fermentasi sekam padi yang telah diamoniasi terhadap kandungan lignin, selulosa dan hemiselulosa. Hipotesis yang digunakan dalam penelitian ini adalah peningkatan aras starter $A$. niger pada persentase tertentu dalam proses 
fermentasi sekam padi amoniasi dapat menurunkan kadar lignin, selulosa dan hemiselulosa.

\section{MATERI DAN METODE}

Penelitian dilaksanakan di Laboratorium Teknologi Pakan serta Laboratorium IImu Nutrisi dan Pakan, Fakultas Peternakan dan Pertanian, Universitas Diponegoro, Semarang. Bahan yang digunakan adalah adalah sekam padi, urea, air, starter $A$. niger.

Metode penelitian menggunakan rancangan acak lengkap (RAL) dengan masing-masing 3 perlakuan menggunakan 5 ulangan. Perbedaan pemberian aras starter yaitu : $0 \%\left(T_{0}\right), 2,5 \%\left(T_{1}\right), 5 \%\left(T_{2}\right)$. Sekam padi di amoniasi terlebih dahulu selama 21 hari, kemudian dilanjutkan dengan fermentasi selama 10 hari. Parameter yang diamati adalah lignin, selulosa dan hemiselulosa. Lignin, selulosa dan hemiselulosa dapat dihitung menggunakan metode Van Soest (1982) :
Analisis kadar selulosa dan lignin (Harris, 1970). Prosedur pertama adalah residu ADF dalam kaca krusibel diletakkan di atas nampan yang dialiri air setinggi lebih kurang $1 \mathrm{~cm}$. Kemudian ditambahkan $\mathrm{H}_{2} \mathrm{SO}_{4} 72 \%$ setinggi lebih kurang $3 / 4$ bagian dari krusibel dan dibiarkan hingga tiris. Lalu dilakukan penyaringan dengan bantuan pompa vacuum. Residu yang sudah tersaring kemudian dicuci dengan air panas dengan suhu $\pm 80^{\circ} \mathrm{C}$ dan dilanjutkan dengan pencucian menggunakan alkohol $90 \%$ yang diulangi sampai dua kali. Residu kemudian dikeringkan dalam oven bersuhu $105^{\circ} \mathrm{C}$ selama 8 jam lalu ditimbang.dan selanjutnya dilakukan pendinginan dengan desikator dan ditimbang. Kemudian pemanasan dalam tanur $500^{\circ} \mathrm{C}$, didinginkan dalam desikator dan ditimbang. Perhitungan kadar selulosa dan lignin dapat dihitung dengan rumus:

$$
\begin{gathered}
\text { Kadar NDF }=\frac{(\text { Berat krusibel }+ \text { Residu })(g)-\text { Berat krusibel }(g)}{\text { Berat sampel }(g) \times \% \text { Bahan kering sampel }} \times 100 \% \\
\text { Kadar ADF }=\frac{(\text { Berat krusibel }+ \text { Residu })(g)-\text { Berat krusibel }(g)}{\text { Berat sampel }(g) \times \% \text { Bahan kering sampel }} \times 100 \% \\
\text { Kadar Hemiselulosa }=\text { Kadar NDF }(\%)-\text { Kadar ADF }(\%) \\
\text { Kadar Selulosa }=\frac{\text { Berat krusibel + Residu ADF }(g)-\text { Berat krusibel }+ \text { Residu } \mathrm{H}_{2} \mathrm{SO}_{4} 72 \% \text { oven }(\mathrm{g})}{\text { Berat sampel }(\mathrm{g}) \times \% \text { Bahan kering sampel }} \times 100 \% \\
\text { Kadar Lignin }=
\end{gathered}
$$

Data yang diperoleh dianalisis dengan sidik ragam (ANOVA) dan jika berpengaruh nyata akan diuji lebih lanjut dengan Uji Jarak Duncan untuk mengetahui perbedaan nilai tengah antar perlakuan.

\section{HASIL DAN PEMBAHASAN Hemiselulosa}

Berdasarkan Tabel 1 didapatkan rata-rata kadar hemiselulosa sekam padi fermentasi tertinggi hingga terendah 
berturut-turut $\mathrm{T}_{0}(0 \%)$ 17,03\%, $\mathrm{T}_{1}(2,5 \%)$ $14,31 \%$ dan $\mathrm{T}_{2}(5 \%) 12,28 \%$. Hasil kadar hemiselulosa sekam padi fermentasi lebih rendah dibandingkan dengan sekam padi tanpa perlakuan dan sekam padi amoniasi (21,88\% dan $20,37 \%$ ). Hal ini dapat terjadi karena proses fermentasi oleh $A$. niger memproduksi enzim selulase untuk menghidrolisis hemiselulosa sekam padi amoniasi. Rahmawati (2014) menyatakan bahwa hemiselulosa dapat dihidrolisis oleh enzim pencerna serat. Hemiselulosa merupakan kelompok polisakarida heterogen dengan berat molekul rendah dan relatif lebih mudah dihidrolisis dengan asam menjadi monomer yang mengandung glukosa, mannosa, galaktosa, xilosa dan arabinosa. Said (1996) menyatakan bahwa hemiselulosa dapat difermentasi oleh beberapa mikroorganisme yang mampu menggunakan gula pentosa sebagai substratnya.

Tabel 1. Pengaruh Perbedaan Aras Starter terhadap Kadar Hemiselulosa Fermentasi Sekam Padi Amoniasi

\begin{tabular}{|c|c|c|c|}
\hline & & lakı & \\
\hline Ulangan & $T_{0}$ & $\mathrm{~T}_{1}$ & $T_{2}$ \\
\hline
\end{tabular}

\begin{tabular}{cccc} 
& $(\%)--$ & & \\
$\mathrm{U}_{1}$ & 17,93 & 13,99 & 13,69 \\
$\mathrm{U}_{2}$ & 19,79 & 13,82 & 10,69 \\
$\mathrm{U}_{3}$ & 15,45 & 14,17 & 13,00 \\
$\mathrm{U}_{4}$ & 15,87 & 15,31 & 12,73 \\
$\mathrm{U}_{5}$ & 16,12 & 14,27 & 11,31 \\
\hline Rata-rata & $17,03^{\mathrm{a}}$ & $14,31^{\mathrm{b}}$ & $12,28^{\mathrm{c}}$ \\
\hline
\end{tabular}

Superskrip yang berbeda pada baris ratarata yang sama menunjukkan perbedaan nyata $(P<0,05)$.

Hasil analisis ragam menunjukkan ada pengaruh yang nyata $(\mathrm{P}<0,05)$, perlakuan perbedaan aras starter $A$. niger terhadap kadar hemiselulosa sekam padi amoniasi yang di fermentasi. Hasil yang didapat adalah kadar hemiselulosa semakin berkurang dari perlakuan aras starter $0 \%\left(\mathrm{~T}_{0}\right)$ hingga perlakuan aras starter $5 \% \quad\left(\mathrm{~T}_{2}\right)$. Menurut Rahmawati (2014) hemiselulosa merupakan heteropolisakarida yang mengandung berbagai gula, terutama pentose. Hemiselulosa umumnya terdiri dari dua atau lebih residu pentose yang berbeda. Komposisi polimer hemiselulosa sering mengandung asam uronat sehingga mempunyai sifat asam. Hemiselulosa memiliki derajat polimerisasi yang lebih rendah, lebih mudah dipecah dibandingkan selulosa dan tidak berbentuk serat-serat yang panjang. Suparno dan Danielli (2017) menyatakan bahwa hemiselulosa dan selulosa lebih mudah di pecah secara enzimatik (selulase).

Hasil uji lanjut menggunakan uji wilayah berjarak Duncan terhadap kandungan hemiselulosa sekam padi fermentasi menunjukkan bahwa perlakuan aras starter $T_{2}(12,38 \%)$ nyata $(P<0,05)$ lebih rendah dibandingkan dengan perlakuan $T_{0}(17,03 \%)$ dan $T_{1}(14,31 \%)$. Hemiselulosa terpecah menjadi pentose, xilosa dan galaktosa saat fermentasi sehingga dapat menyebabkan kandungan hemiselulosa menurun. Morrison (1986) menyatakan bahwa hemiselulosa mempunyai rantai pendek dibandingkan selulosa dan merupakan polimer campuran dari berbagai senyawa gula, seperti xilosa, arabinosa, dan galaktosa. Reksohadiprodjo (1985) menyatakan bahwa rendahnya kandungan hemiselulosa dapat terjadi karena hemiselulosa dipecah oleh mikroba 
menjadi gula pentose selama proses fermentasi. Hemiselulosa yang terpecah tersebut menyebabkan kandungan hemiselulosa setelah fermentasi berkurang.

\section{Selulosa}

Berdasarkan Tabel 2 didapatkan rata-rata kadar selulosa sekam padi fermentasi semakin berkurang berturutturut $\mathrm{T}_{0}(0 \%) 23,89 \%, \mathrm{~T}_{1}(2,5 \%) 20,55 \%$ dan $\mathrm{T}_{2}(5 \%)$ 17,55\%. Hasil kadar selulosa sekam padi fermentasi lebih rendah dibandingkan dengan sekam padi tanpa dilakukan perlakuan dan sekam padi amoniasi (26,94\% dan 25,79\%).

Tabel 2. Pengaruh Perbedaan Aras Starter terhadap Kadar Selulosa

Fermentasi Sekam Padi Amoniasi

\begin{tabular}{cccc}
\hline \hline \multirow{2}{*}{ Ulangan } & \multicolumn{3}{c}{ Perlakuan } \\
\cline { 2 - 4 } & $\mathrm{T}_{0}$ & $\mathrm{~T}_{1}$ & $\mathrm{~T}_{2}$ \\
\hline & (\%)------------------------- \\
$\mathrm{U}_{1}$ & 24,05 & 20,59 & 18,12 \\
$\mathrm{U}_{2}$ & 24,38 & 19,89 & 16,05 \\
$\mathrm{U}_{3}$ & 22,01 & 19,99 & 19,50 \\
$\mathrm{U}_{4}$ & 25,36 & 21,98 & 18,22 \\
$\mathrm{U}_{5}$ & 23,66 & 20,33 & 15,88 \\
\hline Rata-rata & $23,89^{\mathrm{a}}$ & $20,55^{\mathrm{b}}$ & $17,55^{\mathrm{c}}$ \\
\hline
\end{tabular}

Superskrip yang berbeda pada baris ratarata yang sama menunjukkan perbedaan nyata $(P<0,05)$.

Hal ini terjadi karena adanya perlakuan fermentasi yang dapat menurunkan kandungan selulosa dengan bantuan enzim selulase yang diproduksi oleh kapang $A$. niger. Penelitian Rahmawati (2014) menyatakan bahwa enzim selulase merupakan salah satu enzim yang dihasilkan oleh mikroorganisme yang berfungsi untuk mendegradasi selulosa menjadi glukosa. Widayati dan Widalestari (1996) menyatakan bahwa dalam proses fermentasi, mikroba dapat memecah komponen yang kompleks menjadi zat-zat yang lebih sederhana agar mudah dicerna oleh ternak, serta dapat memecah selulosa dan hemiselulosa menjadi gula sederhana dan turunannya yang mudah dicerna.

Hasil analisis ragam menunjukkan ada pengaruh yang nyata $(\mathrm{P}<0,05)$, perlakuan perbedaan aras starter $A$. niger terhadap kadar selulosa sekam padi amoniasi yang di fermentasi. Hasil yang didapat adalah kadar selulosa berkurang dari perlakuan aras starter $0 \%\left(\mathrm{~T}_{0}\right)$ hingga perlakuan aras starter 5\% ( $\left.\mathrm{T}_{2}\right)$. Hal ini dapat terjadi karena saat amoniasi amonia terfiksasi ke dalam sekam sehingga dapat menyebabkan perubahan komposisi dan struktur dinding sel yang berperan untuk merenggangkan ikatan antara lignin dengan selulosa sehingga meningkatkan fleksibilitas dinding sel hingga memudahkan penetrasi oleh enzim selulase. Badrudin (2011) menyatakan bahwa amonia yang terdapat dalam urea saat amoniasi berperan untuk mengubah struktur serat, dengan merenggangnya ikatan antara lignin dengan selulosa akan memudahkan penetrasi enzim selulase. Menurut Amin et al. (2016) perlakuan amoniasi pada jerami padi berakibat terjadinya pemutusan ikatan antara lignin dengan polisakarida penyusun dinding sel yang akan menurunkan kandungan selulosa jerami padi.

Hasil uji lanjut menggunakan uji wilayah berjarak Duncan terhadap kandungan selulosa sekam padi fermentasi menunjukkan bahwa perlakuan aras starter $\mathrm{T}_{2}(17,55 \%)$ nyata $(\mathrm{P}<0,05)$ 
lebih rendah dibandingkan dengan perlakuan $\mathrm{T}_{0}(23,89 \%)$ dan perlakuan $\mathrm{T}_{1}$ $(20,55)$. Hal ini menunjukan bahwa saat proses fermentasi starter $A$. niger dapat menghasilkan enzim selulase untuk membantu penetrasi pada saat fermentasi sehingga kandungan selulosa menurun. Gunam et al. (2010) menyatakan bahwa $A$. niger termasuk kapang yang bisa menghasilkan enzim selulase. Rahmawati (2014) menyatakan bahwa penurunan kandungan selulosa dapat terjadi selama proses fermentasi disebabkan oleh adanya enzim selulase yang diproduksi oleh kapang.

\section{Lignin}

Berdasarkan Tabel 3 didapatkan rata-rata kadar lignin sekam padi fermentasi terendah pada perlakuan aras starter $0 \%$ (T0) sebesar 30,61\% dan tertinggi pada perlakuan aras starter 5\% (T2) sebesar 32,21\%. Hasil kadar lignin sekam padi fermentasi lebih tinggi dibandingkan dengan sekam padi tanpa dilakukan perlakuan dan sekam padi amoniasi (30,38\% dan 30,39\%). Hal ini dapat terjadi karena pada lignin dan hemiselulosa berikatan sebagai komponen dinding sel, ketika ikatan tersebut terpisah dan hemiselulosa berkurang maka mengakibatkan porsi lignin meningkat. Menurut Nelson dan Suparjo (2011), degradasi lignin akan membuka akses untuk perombakan selulosa dan hemiselulosa. Crampton dan Haris (1969) menyatakan bahwa menurunnya hemiselulosa dan penurunan kadar NDF mengakibatkan meningkatnya lignin.

Tabel 3. Pengaruh Perbedaan Aras Starter terhadap Kadar Lignin Fermentasi Sekam Padi Amoniasi

\begin{tabular}{|c|c|c|c|}
\hline \multirow{2}{*}{ Ulangan } & \multicolumn{3}{|c|}{ Perlakuan } \\
\hline & $\mathrm{T}_{0}$ & $\mathrm{~T}_{1}$ & $\mathrm{~T}_{2}$ \\
\hline & - - - & & $--(\%)--$ \\
\hline$U_{1}$ & 27,74 & 32,16 & 32,23 \\
\hline $\mathrm{U}_{2}$ & 30,90 & 31,10 & 36,42 \\
\hline $\mathrm{U}_{3}$ & 32,56 & 29,70 & 33,04 \\
\hline$U_{4}$ & 28,56 & 30,71 & 29,12 \\
\hline$U_{5}$ & 33,28 & 33,86 & 30,25 \\
\hline Rata-rata & 30,61 & 31,50 & 32,21 \\
\hline
\end{tabular}

Hasil analisis ragam menunjukkan tidak ada pengaruh yang nyata $(P<0,05)$, perlakuan perbedaan aras starter $A$. niger terhadap kadar lignin sekam padi amoniasi yang di fermentasi. Hasil yang didapat adalah kadar lignin semakin meningkat secara matematis hingga perlakuan $\mathrm{T}_{2}$ (5\%). Hal ini dapat terjadi karena $A$. niger bersifat selulolitik dan memproduksi selulase sehingga pada saat proses fermentasi hanya terjadi pemisahan ikatan lignin dengan selulosa dan hemiselulosa teetapi tidak menurunkan kandungan lignin. Rachma et al. (2017) menyatakan bahwa sebagian besar Aspergillus sp. memproduksi berbagai enzim seperti selulase, amilase, glukoamilase, lipase dan protease salah satunya adalah $A$. niger. Judoamidjojo et al. (1992) menyatakan bahwa enzim selulase tidak dapat bekerja pada lignin, hal tersebut dikarenakan lignin berukuran makro molekul (BM 38.00-75.000) sehingga enzim selulase tidak dapat berpenetrasi ke dalam lapisan lignin yang dilindungi oleh selulosa dan hemiselulosa.

\section{KESIMPULAN DAN SARAN}

Berdasarkan hasil penelitian dapat disimpulkan bahwa penambahan aras starter $A$. niger hingga $5 \%$ dalam proses fermentasi sekam padi amoniasi dapat 
menurunkan kadar selulosa dan hemiselulosa tetapi tidak menurunkan kadar lignin.

Untuk meningkatkan kualitas sekam padi dapat dilakukan dengan amoniasi dengan kadar amonia 5\% selama 21 hari dan fermentasi menggunakan starter $A$. niger dengan aras $5 \%$ selama 10 hari.

\section{DAFTAR PUSTAKA}

Amin, M., Hasan, S. D., Yanuarianto, O., lqbal, M. dan Karda., I W. 2016. Peningkatan kualitas jerami padi menggunakan teknologi amoniasi fermentasi. Jurnal IImu dan Teknologi Peternakan Indonesia 2 (1): $96-103$.

Badan Pusat Statistik Provinsi Jawa Tengah. 2018. Luas Panen dan Produksi Padi di Jawa Tengah 2018. Semarang : Berita Resmi Statistik No. 76/11/33/Th. XI, 1 November 2018.

Badrudin, U. 2011. Teknologi amoniasi untuk mengolah limbah jerami padi sebagai sumber pakan ternak bermutu di desa pabuaran kecamatan bantarbolang kabupaten pemalang. ABDIMAS 15 (1): $52-58$.

Crampton, E. W. dan L. E. Haris. 1969. Applied Animal Nutrition $1^{\text {st }}$ Edition. The Engsminger Publishing Company, California.

Gunam, I.B., K. Buda, I.M.Y.S. Guna. 2010. Pengaruh perlakuan delignifikasi dengan larutan $\mathrm{NAOH}$ dan konsentrasi substrat jerami padi terhadap produksi enzim selulase dari Aspergillus niger NRRL A-II, 264. Jurnal Biologi 14 (1): 55 - 61.

Harris, L. E. 1970. Nutrition Research Techniques for Domestic and Wild Animals. Departemen Animal Nutrition Utah State University, Logan.

Judoamidjojo, M., A. A. Darwis dan E. G. Sa'id. 1992. Teknologi Fermentasi. Penerbit Rajawali Press dengan Pusat Antar Universitas Bioteknologi IPB, Jakarta.

Morrison, I. M. $1986 . \quad H e m i c e l l u l o s e$ contamination of acid detergent residues and their replacement by cellulose residues in cell wall analysis. Journal Science Food Agriculture 31 (1) : 639 - 645.

Nelson dan Suparjo. 2011. Penentuan lama fermentasi kulit buah kakao dengan phanerochaete chrysosporium: evaluasi kualitas nutrisi secara kimiawi. AGRINAK 1 (1) : 1 - 10.

Partama, I. B. G., T. G. B. Yadnya, dan A. A. A. S. Trisnadewi. 2018. Pemanfaatan sekam padi teramoniasi serta terbiofermentasi dalam ransum disuplementasi daun sirih (Piper betle) terhadap penampilan itik bali betina fase pertumbuhan. Majalah IImiah Peternakan 21 (2) : 51 - 55.

Rachma, A. S., E. Kusdiyantini dan M. G. I. Rukmi. 2017. Produksi selulase oleh kapang Aspergillus sp. hasil isolasi dari limbah pengolahan sagu (Metroxylon sp.) dengan variasi konsentrasi inokulum pada 
fermentasi terendam statis. Jurnal Biologi 6 (1): $11-20$.

Rahmawati. 2014. Kandungan ADF, NDF, Selulosa, Hemiselulosa, dan Lignin Silase Pakan Komplit Berbahan Dasar Rumput Gajah (Pennisetum purpureum) dan Beberapa Level Biomassa Murbei (Morus alba). Universitas Hasanuddin, Makassar (Skripsi).

Reksohadiprodjo, S. 1985. Produksi Tanaman Hijauan Makanan Ternak Tropik. BPFE Yogyakarta, Yogyakarta.

Said, E. G. 1996. Penanganan dan Pemanfaatan Limbah Kelapa Sawit. Cetakan 1 Trubus Agriwidya, Ungaran.

Soltani, N., A. Bahrami, M. I. G. Pech, dan L. A. Gonzalez. 2015. Review on the physicochemical treatments of rice husk for production of advanced materials. Chemical Engineering Journal 264 (8) : 899 - 935.

Sukaryana, Y., U. Atmomarsono, V. D. Yunianto dan E. Supriyatna. 2011. Peningkatan nilai kecernaan protein kasar dan lemak kasar produk fermentasi campuran bungkil inti sawit dan dedak padi pada broiler. JITP 1 (3) : 167 - 172.

Suparno, O. dan R. Danieli. 2017. Penghilangan hemiselulosa serat bambu secara enzimatik untuk pembuatan serat bambu. Jurnal Teknologi Industri Pertanian 27 (1): 89 - 95.

Van Soest, P.J. 1982. Nutritional Ecology of The Ruminant. Ruminant Metabolism, Nutritional Strategies. The Cellulolytic Fermentation and The Chemistry of Forages and Plants Fibers. Published and Distributed by O \& Books. Inc. Corvallis, Oregon.

Widayati, E. Dan Y. Widalestari. 1996. Limbah Untuk Pakan Ternak. Trubus Agrisana, Surabaya.

Y.P. Widodo, L.L. Nuswantara, dan F. Kusmiyati. (2016). Kesernaan dan Fermentabilitas Nutrien Rumput Gajah Secara In Vitro Ditanam dengan Pemupukan Arang Aktif Urea. 